\title{
The true absorption of cyst(e)ine from the ovine small intestine
}

\author{
By R. ELLIO'TT* AND D. A. LITTLE† \\ Department of Agricultural Biochemistry, University of Newcastle upon Tyne, \\ Newcastle upon Tyne $N E_{\mathrm{I}}{ }_{7} R U$
}

(Received 24 November 1976-Accepted 6 December 1976)

\begin{abstract}
I. $\mathrm{Na}_{2}{ }^{34} \mathrm{SO}_{4}$ was infused into the rumen of a sheep fed a dried grass diet.
2. The digesta at the pylorus which contained ${ }^{35} \mathrm{~S}$-labelled cyst(e)ine synthesized by the rumen microflora was collected and mixed with chromium EDTA. This material was infused into the duodenum of ${ }^{35} \mathrm{~S}$ free sheep.

3. Ileal digesta was subsequently collected and analysed for cyst(e)ine ${ }^{35} \mathrm{~S}$ and $\mathrm{Cr}$.

4. The proportion of the labelled cyst(e)ine truly absorbed from the small intestine was $0.72 \pm 0.004$.
\end{abstract}

The extent of digestion and absorption of microbial protein in the ruminant small intestine is of great significance to the protein nutrition of the animal. It has been reported by Coelho da Silva, Seeley, Beever, Prescott \& Armstrong (1972) that the proportion of amino acid $\mathrm{N}$ digested in the ovine small intestine ranged from 0.67 to 0.79 . Hogan (1973) reported that the mean proportion of the amino acids digested in sheep fed subterranean clover was 0.72 . On any one diet it appears that the absorption of essential amino acids is higher than the non-essential ones (MacRae \& Ulyatt, 1974). On different diets the digestibility of any one amino acid varies considerably but a feature of most studies is the high value for methionine. However, values for cyst(e)ine digestibility are consistently low. Coelho da Silva et al. (1972) reported values ranging from 0.25 to 0.57 . In a series of experiments in which sheep were fed purified diets containing urea, casein or maize gluten as dietary nitrogen sources the apparent digestibility (proportional basis) of cyst(e)ine ranged from 0.37 to 0.52 (Elliott, unpublished results). Adequate supply of cyst(e)ine is very important to the ovine because of the large cyst(e)ine requirement for wool keratin (Ryder \& Stephenson, 1968) and the partial methionine-sparing effect which cyst(e)ine exhibits.

A technique was therefore developed to measure the true absorption of cyst(e)ine in the ovine small intestine.

\section{EXPERIMENTAL}

\section{Sheep and their management}

The five sheep were all mature Scottish Blackface wethers, each fitted with a rumen cannula and re-entrant duodenal and ileal cannulae (Brown, Armstrong \& MacRae, 1968). Each animal was housed individually in a metabolism cage and fed

* Present address: Boots Research Station, The Priory, Thurgarton, Nottinghamshire.

+ Present address: C.S.I.R.O., Division of Tropical Crops and Pastures, St Lucia, Q.4067, Australia. 
a diet of pelleted dried grass $(900 \mathrm{~g} / 24 \mathrm{~h})$ in two equal amounts at 09.00 hours and I6.00 hours.

One animal was infused continuously with a solution of $\mathrm{Na}_{2}{ }^{35} \mathrm{SO}_{4}$ intraruminally at the rate of $500 \mathrm{ml}$ and $150 \mu \mathrm{Ci}{ }^{35} \mathrm{~S} / \mathrm{d}$. The digesta flowing through the pylorus, which contained ${ }^{35} \mathrm{~S}$-labelled cyst(e)ine synthesized by microbial activity in the rumen, was collected and mixed with Cr EDTA (Binnerts, van't Klooster \& Frens, 1968) before infusion into four other sheep that were free of ${ }^{35} \mathrm{~S}$. Approximately $500 \mathrm{ml}$ of the collected material was infused over $2 \mathrm{~h}$ into the duodenum of each of these animals while the digesta flowing through the pylorus was diverted. Normal flow was re-established following the infusion. Total collections of ileal digesta were commenced $4 \mathrm{~h}$ after the start of infusion and were continued for $7.5 \mathrm{~h}$.

\section{Analyses}

Samples of the infused digesta and of the ileal digesta were homogenized, freeze dried and ground to fine powders before analysis. The $\left[{ }^{35} \mathrm{~S}\right] \mathrm{cyst}(\mathrm{e})$ ine content of these samples was determined (Elliott, 1975). The chromium determination was that reported by Christian \& Coup (1954). A $3 \%$ correction factor was applied to allow for $\mathrm{Cr}$ absorption (Binnerts et al. 1968 ) and the change in the ratio, $\left.{ }^{35} \mathrm{~S}\right] \mathrm{cyst}(\mathrm{e})$ ine: $\mathrm{Cr}$ between infusate and ileal digesta was interpreted as the measure of true absorption of cyst(e)ine in the small intestine.

As the analytical technique used for the detection of cyst(e)ine only quantified the sulphur in the amino acid it could not be concluded definitely that the entire amino acid was absorbed, although the inference must be that this did occur.

\section{RESULTS AND DISCUSSION}

The proportions of ${ }^{35} \mathrm{~S}$-labelled cyst(e)ine truly digested and absorbed from the small intestine of the four sheep were respectively $0.83,0.73,0.66$ and 0.67 (see Table I). The mean of $0.72( \pm 0.004, \mathrm{SE})$ was in close agreement with that of $0.7 \mathrm{I}$ (Bird, 1972) which was derived following the abomasal infusion of rumen bacteria labelled with ${ }^{35} \mathrm{~S}$ during growth in vitro and the measurement of the faecal and urinary excretion of isotope. Implicit in the derivation of the figure of 0.72 absorption in this present work is the assumption that recycling of absorbed $\left.{ }^{35} \mathrm{~S}\right] c y s t(e)$ ine within the small intestine had not occurred in the short period involved. The close agreement with the results of Bird (1972) in which a different experimental procedure was adopted, suggests that this assumption is valid.

Mason (1969) derived a true digestibility figure of 0.69 in sheep based on calculation involving estimates of the uptake and excretion of bacterial N. Salter \& Smith (1974) harvested ${ }^{15} \mathrm{~N}$-labelled rumen micro-organisms from steers given various diets which incorporated $\left[{ }^{15} \mathrm{~N}\right]$ urea, incubated them with pepsin before infusing them into the duodenum of a calf, collected the digesta at the ileum and measured the disappearance of isotope through the small intestine. They obtained a mean figure for absorption of 0.64 although the individual values were very variable. This variability was attributed to the differing diets fed to the steers from which the 
Table I. The true absorption of cyst(e)ine $S$ in the ovine small intestine

\begin{tabular}{|c|c|c|c|c|c|}
\hline & $\begin{array}{c}\mathrm{Cr} \\
(\mathrm{mg} / \mathrm{g} \mathrm{DM})\end{array}$ & $\begin{array}{c}\text { Corrected } \\
\mathrm{Cr}\end{array}$ & $\begin{array}{l}{\left[{ }^{35} \mathrm{~S}\right] \mathrm{cyst}(\mathrm{e}) \text { ine }} \\
(\mathrm{NCPM} / \mathrm{g} \text { DM) }\end{array}$ & $\underset{\mathrm{Cr}}{\text { Activity }}$ & $\begin{array}{l}\text { Proportion of } \\
\text { cyst(e)ine } S \\
\text { absorbed }\end{array}$ \\
\hline Infusate $\ldots$ & 18.03 & - & $1006 \cdot 8$ & $55 \cdot 84$ & - \\
\hline \multicolumn{6}{|l|}{ Ileal } \\
\hline Sheep I & $5 \cdot 32$ & $5 \cdot 48$ & $53 \cdot 3$ & $9 \cdot 73$ & 0.83 \\
\hline Sheep 2 & $5 \cdot 20$ & $5 \cdot 36$ & $82 \cdot 0$ & $15.3^{\circ}$ & 0.73 \\
\hline Sheep 3 & 4.45 & 4.59 & $88 \cdot I$ & 10.19 & 0.66 \\
\hline Sheep 4 & 4.90 & 5.05 & $92 \cdot 7$ & $18 \cdot 3^{6}$ & 0.67 \\
\hline
\end{tabular}

rumen bacteria were harvested. Support for their view can be found in the work of Burris, Bradley \& Boling (1974). They isolated bacteria from the rumen of steers fed a basal corn silage ration to which had been added soya-bean meal, fish meal or linseed meal and then measured the concentration of amino acids released from the bacteria after an in vitro pepsin pancreatic digestion. Although there were no differences in the amino acid composition of the bacteria, the release of total amino acids and of threonine, serine, glutamic acid, valine, methionine, phenylalanine and lysine varied significantly among treatments.

On the basis of the present results it would appear that the low apparent digestibility of cyst(e)ine noted by various workers and reported in the introduction, implies appreciable endogenous secretions of cyst(e)ine in the small intestine. However, it must be noted that Bergen, Purser \& Cline (1967) have shown considerable variation in the in vitro digestibility of rumen bacteria, and it may be that the low values previously reported relate to microbial biomass in which the cyst(e)ine was of low digestibility.

We wish to thank Professor D. G. Armstrong for his generous advice and support in the conduct of this work.

\section{REFERENCES}

Bergen, W. G., Purser, D. B. \& Cline, J. H. (1967). Y. Nutr. 92, 357.

Binnerts, W. 'T., van't Klooster, A. Th. \& Frens, A. M. (1968). Vet. Rec. 82, 470.

Bird, P. H. (1972). Aust. F. biol. Sci. 25, 195.

Brown, G. F., Armstrong, D. G. \& MacRae, J. C. (I968). Br. vet. F. 124, 78.

Burris, W. R., Bradley, N. W. \& Boling, J. A. (1974). F. Anim. Sci. 38, 200.

Coelho da Silva, J. F., Seeley, R. C., Beever, D. E., Prescott, J. H. D. \& Armstrong, D. G. (r972). Br. F. Nutr. 28, 357 .

Christian, K. B. \& Coup, M. R. (1954). N.Z. Fl Sci. Technol. A 36, 328.

Elliott, R. (1975). Newsletter on the Application of Nuclear Methods in Biology and Agriculture, no. 5, pp. 6.

Hogan, J. P. (1973). Aust. F. Agric. Res. 24, 587.

MacRae, J. C. \& Ulyatt, M. J. (1974). F. agric. Sci., Camb. 82, 309.

Mason, V. R. (1969). F. agric. Sci., Camb. 73, 99.

Ryder, M. L. \& Stephenson, S. K. (1968). Wool Growth. London: Academic Press.

Salter, D. N. \& Smith, R. H. (1974). Proc. Nutr. Soc. 33, 42 A. 